\title{
RANCANGAN PROGRAM SISTEM PRESENSI PENGUNJUNG BERBASIS ICT DI PERPUSTAKAAN UNIVERSITAS PENDIDIKAN GANESHA
}

\author{
Ni Gusti Ayu Ketut Retty Retno Wulan'1 , I Gede Ngurah Sugata ${ }^{2}$ \\ 1,2Universitas Pendidikan Ganesha, Singaraja, Indonesia \\ Email: rettyretnowulan@gmail.com
}

\begin{abstract}
Abstrak
Sistem pendataan presensi pengunjung di perpustakaan pusat Universitas Pendidikan Ganesha saat ini masih menggunakan sistem manual yaitu mewajibkan pengunjung mengisi/menulis data di buku tamu. Dari pengamatan penulis selama menjadi pustakawan terbukti sistem ini memiliki kelemahan yaitu pengunjung sering tidak mengisi data kunjungan. Karena tidak efektifnya pengisian buku data oleh pengunjung maka data statistik pengunjung yang diolah oleh pustakawan tidak bisa mencerminkan kondisi riil di lapangan. Ide membuat program software presensi pengunjung adalah untuk lebih memudahkan pustakawan dalam penyusunan laporan data pengunjung perpustakaan dalam bentuk statistik (grafik dan data tabel) secara cepat dan akurat. Tujuan yang ingin dicapai adalah (1) mendeskripsikan cara menjalankan program sistem otomasi presensi pengunjung perpustakaan berbasis ICT; (2) mengetahui penilaian pustakawan terhadap kinerja program sistem otomasi presensi pengunjung perpustakaan berbasis ICT; dan (3) mengetahui penilaian pakar pemrograman terhadap kualitas program sistem otomasi presensi pengunjung perpustakaan berbasis ICT. Target yang ingin dicapai adalah tersusunnya sistem software yang memudahkan pustakawan menyusun laporan data pengunjung perpustakaan. Desain rancangan yang digunakan dalam penyusunan program ini adalah rancangan Prototype Model, yaitu pengembang dan pelanggan dapat saling berinteraksi selama proses pembuatan sistem. Pengembangan dimulai dari studi masalah dan berlanjut dengan analisis konteks, penyusunan konsep, penyusunan desain, penyusunan rancangan, validasi konsep, uji rancangan, dan penyerahan program software. Penilaian hasil penelitian menggunakan format instrumen kinerja dan kualitas program. Hasil penelitian menunjukkan bahwa (1) operasional program relatif praktis, tampilan program sangat sederhana dan mudah dipahami; (2) kinerja program dinilai "sangat baik", dan (3) kualitas program ini dinilai "sangat baik", sehingga layak untuk diterapkan.
\end{abstract}

Kata Kunci: Sistem Otomasi Presensi, Information Communications Technologies (ICT).

\begin{abstract}
Presence visitor data collection system in the central library Ganesha University of Education are still using manual systems that require visitors to fill out / write data in the guest book. From the writer's observation during the librarian proven this system has the disadvantage that visitors often do not fill in the traffic data. Because of the ineffectiveness of books filling the data by the visitor statistics of visitors processed by the librarian can not reflect the real situation on the ground. The idea of making the visitor Presence software program is to make it easier for librarians in the preparation of the data report library visitors in the form of statistics (graphs and data tables) quickly and accurately. The objectives are (1) to describe how to run the program automation system Presence of ICT-based library patrons; (2) determine the librarian of the performance appraisal program automation system Presence of ICT-based library patrons; and (3) determine the programming expert assessment of the quality program automation system Presence of ICT-based library visitors. Targets are drafting software system that allows librarians prepared a report on visitor data library. Draft design used in the preparation of this program is the design of prototype models, which developers and customers can interact with each other during the manufacturing process of the system. Development starts from the study of the problem and continues with context analysis, drafting, drafting design, drafting, validation of concepts, test design, and
\end{abstract}


delivery of software programs. Assessment results of studies using the instrument format of performance and quality of programs. The results showed that (1) a relatively practical operational program, the program display is very simple and easy to understand; (2) the performance of the program was rated "very good", and (3) the quality of the program is rated "very good", making it feasible to implement.

\section{Keywords: Presence Automation Systems, Information Communications Technologies (ICT)}

\section{PENDAHULUAN}

Data merupakan bahan mentah yang akan berguna bila diolah menjadi suatu informasi. Dengan kata lain, data yang telah diperoleh harus diukur dan dinilai baik buruknya, berguna atau tidak dalam hubungannya dengan tujuan yang akan dicapai. Pengolahan data terdiri dari kegiatan-kegiatan penyimpanan data dan penanganan data (Tata, S., 2005:21). Sistem pengolahan data saat ini berkembang sangat pesat dengan ditemukannya teknologi ICT (Information Communications Technologies). Teknologi ini telah banyak membawa perubahan dalam pengelolaan perpustakaan.

Penggunaan sistem otomasi data perpustakaan berbasis ICT (termasuk di sini sistem presensi pengunjung) sangat berarti bagi pustakawan karena mampu memberi banyak manfaat, diantaranya adalah meningkatkan efisiensi kerja, memiliki akurasi data yang tinggi, dapat mengefektifkan kerja pengelolaan seperti pengelolaan data, dan utamanya mampu meningkatkan kualitas layanan informasi, baik layanan informasi berbentuk data maupun analisis data (statistik). Otomasi data perpustakaan adalah sebuah proses pengelolaan data perpustakaan dengan menggunakan bantuan ICT (Nur, 2007:5) Dengan bantuan ICT maka beberapa pekerjaan manual dapat dipercepat dan diefisienkan, proses pengolahan data koleksi menjadi lebih akurat dan lebih cepat untuk ditelusur kembali. Dengan demikian para pustakawan dapat menggunakan waktu lebihnya untuk pengembangan perpustakaan karena beberapa pekerjaan yang mempunyai sifat berulang (repeatable) sudah diambil alih oleh komputer. Adapun alasan lain dilakukannya suatu sistem otomasi presensi data perpustakaan adalah dalam rangka mengefisienkan dan mempermudah pekerjaan perpustakaan, dalam memberikan layanan yang lebih baik kepada pengguna perpustakaan, dan meningkatkan citra perpustakaan (Gatot Subroto, 2010:3).

Perpustakaan Undiksha sebagai salah satu perguruan tinggi negeri di Bali telah memanfaatkan perkembangan ICT. Upayaupaya perpustakaan Undiksha dalam memanfaatkan keunggulan teknologi ini telah dilakukan seperti dalam peningkatan layanan informasi berbasis ICT telah dikelola dengan sistem otomasi seperti pengelolaan berbasis jaringan Online Public Access Catalogue (OPAC) yang fungsinya untuk menelusur buku berdasarkan judul dan pengarang sehingga mempermudah pengguna untuk menemukan buku yang dimaksud. Namun sampai saat ini keunggulan sistem pengelolaan data perpustakaan berbasis ICT belum dimanfaatkan dalam pendataan kehadiran (presensi) pengunjung perpustakaan secara otomatis yang terkait dengan kepentingan laporan data (data report) statistik pengunjung perpustakaan.

Sistem pendataan presensi pengunjung di perpustakaan pusat Universitas Pendidikan Ganesha saat ini masih menggunakan sistem manual yaitu mewajibkan pengunjung mengisi/menulis data di buku tamu. Dari pengamatan penulis selama menjadi pustakawan terbukti sistem ini memiliki kelemahan yaitu pengunjung sering tidak mengisi data kunjungan.

Karena tidak efektifnya pengisian buku data oleh pengunjung maka data statistik pengunjung yang diolah oleh pustakawan tidak bisa mencerminkan kondisi riil di lapangan, sehingga laporan data untuk pengunjung perpustakaan bisa diragukan kebenarannya. Permasalahan ini tidak sepenuhnya terletak pada kelemahan atau rendahnya kinerja pustakawan. 
Kondisi sistem yang dibangun yang belum efektif dan permintaan data yang bersifat mendesak seperti keperluan visitasi Dirjen Dikti, keperluan Borang, dan lainnya memberi andil lemahnya laporan data, dimana mengharuskan pustakawan mengambil jalan pintas.

Melihat kondisi ini dimunculkan ide untuk membuat program software presensi pengunjung untuk input data yang selanjutnya diolah oleh komputer menjadi data berbentuk stastistik (grafik dan data tabel) untuk lebih memudahkan dalam penyusunan laporan pustakawan.

ICT atau di Indonesia dikenal sebagai TIK (Teknologi Informasi Komunikasi) merupakan pemrosesan data yang diperoleh dari setiap elemen sistem menjadi bentuk yang mudah dipahami dan merupakan pengetahuan yang relevan dan dibutuhkan, dimana informasi itu sendiri merupakan pernyataan yang menjelaskan suatu peristiwa sehingga manusia dapat membedakan antara satu dengan yang lainnya. Selanjutnya teknologi ini digunakan untuk menyimpan, mengolah, menghasilkan, serta menyebarkan informasi kepada yang memerlukan. Teknologi informasi merupakan mata rantai dari perkembangan SI (Sistem Informasi) Budi Sutedjo (2002:168).

Ada 10 (sepuluh) sifat yang dituntut terkait nilai informasi yang dimiliki oleh produk ICT, yaitu: (1) mudah diperoleh; (2) luas dan lengkap; (3) ketelitian; (4) kecocokan; (5) ketepatan waktu; (6) kejelasan; (7) keluwesan; (8) dapat dibuktikan; (9) tidak ada prasangka; dan (10) dapat diukur.

Sedangkan dilihat tuntutan kualitas informasi dalam sistem informasi, yaitu: akurat (accurate), tepat waktu (timelines), dan relevan (relevance), bisa dikatakan ketiganya mampu ditangani oleh ICT.

Secara teori ICT mampu meningkatkan efektivitas dan efisiensi kerja. Banyak teori terkait pengertian efektif yang dikemukakan beberapa peneliti, seperti Emerson yang dikutip oleh Soewarno Handayaningrat (1994:16) yang menya-takan bahwa "efektivitas adalah peng-ukuran dalam arti tercapainya tujuan yang telah ditentukan sebelumnya."
Tannembaun (1985:50) mengemukakan "efektivitas ditinjau dari sudut pencapaian tujuan, dimana keberhasilan suatu organisasi harus mempertimbangkan bukan saja sasaran organisasi tetapi juga mekanisme mempertahankan diri dalam mengejar sasaran. Dengan kata lain, penilaian efektivitas harus berkaitan dengan mesalah sasaran maupun tujuan". Steers (1985:87) mengemukakan "efektivitas adalah jangkauan usaha suatu program sebagai suatu sistem dengan sumber daya dan sarana tertentu untuk memenuhi tujuan dan sasarannya tanpa melumpuhkan cara dan sumber daya itu serta tanpa memberi tekanan yang tidak wajar terhadap pelaksanaan-nya". Lebih lanjut Agung Kurniawan dalam bukunya Transformasi Pelayanan Publik mendefinisikan efektivitas, adalah "kemampuan melaksanakan tugas, fungsi" (Kurniawan, 2005:109).

Dari beberapa kajian teori yang dilakukan peneliti dapat disimpulkan bahwa efektivitas adalah suatu ukuran yang menyatakan seberapa jauh target (kuantitas, kualitas dan waktu) yang telah dicapai oleh manajemen, yang mana target tersebut sudah ditentukan terlebih dahulu. Hal ini sesuai dengan pendapat yang dikemukakan oleh Hidayat (1986) yang menjelaskan bahwa :"efektivitas adalah suatu ukuran yang menyatakan seberapa jauh target (kuantitas, kualitas dan waktu) telah tercapai. Dimana makin besar persentase target yang dicapai, makin tinggi efektivitasnya".

Efisien dimaksudkan adalah rasio output terhadap input, atau jumlah output per unit input (Anthony, 2005). Dalam beberapa organisasi, efisiensi diukur dengan cara membandingkan biaya aktual dengan standar, dimana biaya-biaya tersebut harus dinyatakan dalam output yang diukur. Efisiensi dan efektivitas berkaitan satu sama lain, setiap pusat tanggung jawab dalam hal ini adalah organisasi, harus efektif dan efisien dimana organisasi harus mencapai tujuannya dengan cara yang optimal. Suatu pusat tanggung jawab yang menjalankan tugasnya dengan konsumsi terendah atas sumber daya, mungkin akan efisien, tetapi 
jika output yang dihasilkannya gagal dalam memberikan kontribusi yang memadai pada pencapaian cita-cita organisasi, maka pusat tanggung jawab tersebut tidaklah efektif. Secara ringkas suatu pusat tanggung jawab akan bersifat efisien jika melakukan sesuatu dengan tepat, dan akan bersifat efektif jika melakukan hal-hal yang tepat.

Setiap pekerjaan yang efektif belum tentu efisien, karena mungkin hasil dicapai dengan penghamburan material, juga berupa pikiran, tenaga, waktu, maupun benda lainnya. Kata efisien sering didahului dengan kata efektif, dimana kedua kata tersebut sangat berhubungan dengan produktivitas dari suatu tindakan atau hasil yang diinginkan. Suatu yang efektif belum tentu efisien, demikian juga sebaliknya suatu yang efisien belum tentu efektif. Dengan demikian istilah efektif adalah melakukan pekerjaan yang benar dan sesuai serta dengan cara yang tepat untuk mencapai suatu tujuan yang telah direncanakan. Sedangkan efisien adalah hasil dari usaha yang telah dicapai lebih besar dari usaha yang dilakukan.

Perpustakaan dengan berbagai ciri khas dan kemampuannya dalam mengelola informasi mempunyai alasan tersendiri mengapa perlu menggunakan ICT sebagai alat bantu, di antaranya adalah (1) sistematika informasi, yaitu terjadi-nya ledakan informasi yang membanjiri dunia saat ini membutuhkan pengelolaan yang lebih sistematis. Hampir semua Perguruan Tinggi di Indonesia meng-gunakan ICT dalam pengelolaan data base perpustakaan; (2) tingginya akses informasi, yaitu kebutuhan pengguna untuk mencari dan menemukan kembali informasi lebih mudah jika difasilitasi dengan sarana ICT. Katalog online memungkinkan pustakawan dan pengguna untuk mendapatkan informasi dari berbagai sumber; (3) efisiensi pekerjaan, di mana komputer di perpustakaan membantu pekerjaan menjadi lebih cepat. Pencatatan buku-buku baru serta pengolahan akan lebih mudah jika disimpan dalam berkas komputer; (4) memudahkan tukar-menukar informasi dalam bentuk data; (5) salinan data atau informasi yang dibuat dapat diseragam-kan sehingga memudahkan pengguna (user friendly). Konsep MARC yang populer tahun 90-an masih digunakan dalam rangka menyeragamkan ketentuan tag (ruas) data bibliografi pustaka; (6) penyajian informasi data yang menarik, bisa sebagai promosi perpustakaan; (7) pengguna dapat belajar dan mencari sendiri informasi yang dibutuhkan dengan bantuan sarana ICT, khususnya komputer.

Saat ini sistem informasi merupakan isu yang paling penting dalam pengendalian manajemen. Hal ini disebabkan karena tujuan dari pengendalian manajemen adalah untuk membantu manajemen dalam mengkoordinasi subunit-subunit dari organisasi dan mengarahkan bagian-bagian tersebut untuk mencapai tujuan organisasi. Dua hal yang menjadi perhatian dari definisi di atas adalah mengkoordinasi dan mengarahkan. Dalam dua proses tersebut diperlukan satu sistem agar proses koordinasi dan pengarahan dapat berjalan secara efektif sehingga tujuan perusahaan dapat tercapai. Manfaat utama dari perkembangan sistem informasi bagi sistem pengendalian manajemen adalah: (1) penghematan waktu, (2) penghematan biaya, (3) peningkatan efektivitas, (4) pengembangan teknologi, dan (5) pengembangan personel akuntansi. Dengan berbagai manfaat dan kontribusi yang diberikan tersebut, diharapkan setiap organisasi dapat meningkatkan kualitas produknya, baik berupa produk layanan maupun produk lainnya.

\section{METODE PENELITIAN}

Penelitian ini mengambil tempat di Universitas Pendidikan Ganesha (Undiksha) jalan Udayana Singaraja. Subjek penelitian adalah seluruh pustakawan di perpustakaan pusat Undiksha dan objeknya kualitas rancangan program sistem otomasi presensi pengunjung perpustakaan berbasis ICT.

Teknik yang digunakan dalam penyusunan rancangan sistem adalah prototype model. Dengan metode prototype ini pengembang (programmer) dan pelanggan (peneliti) dapat saling berinteraksi selama proses pembuatan sistem. Tahap-tahap perancangan dimulai dari pengumpulan data kebutuhan, 
perancangan cepat, bangun prototype, evaluasi prototype, dan perbaikan prototype. Skema paradigma prototype model dapat dilihat pada gambar 1 berikut.

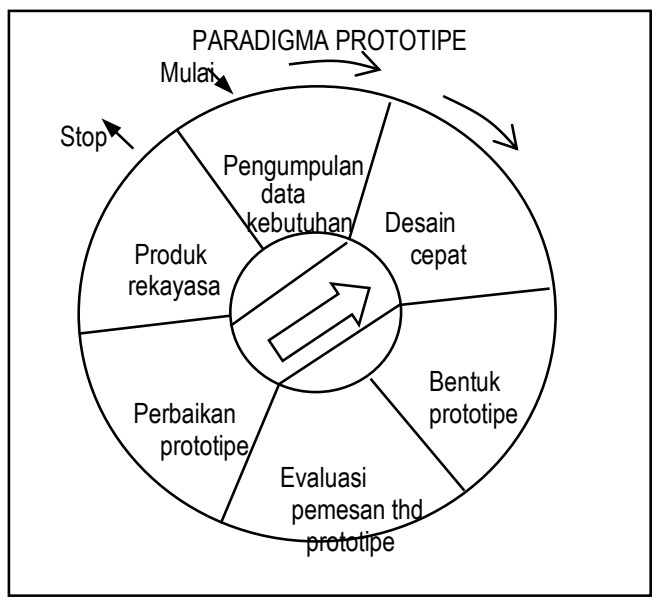

Gambar 1. Desain Prototype Model

Dalam penelitian ini peneliti bukanlah seorang ahli pemrograman. Oleh karena itu peneliti perlu bekerjasama dengan dengan programmer yaitu orang yang berkompeten dalam mengembangkan suatu program software berbasis komputer. Dalam hal ini peneliti selaku pemesan (klien) dan programmer selaku pengembang program (developer). Untuk memperoleh program software yang sesuai dengan konsepkonsep yang dipesan klien, maka perlu kerjasama dalam bentuk komunikasi, informasi, dan data-data yang cukup untuk mendukung kerja programmer hingga terbentuknya program software yang sesuai pesanan.

Prosedur yang dilakukan peneliti yang bekerjasama dengan programmer dalam kegiatan perancangan program software dimulai dari: (1) studi masalah, peneliti melakukan kegiatan pencarian topik permasalahan yang diangkat; (2) analisis kebutuhan, peneliti melakukan analisis kajian terkait kebutuhan yang diperlukan untuk perancangan; (3) penyusunan konsep, peneliti selain mengumpulkan data juga mengumpulkan informasi yang dapat membantu dalam pembuatan rancangan model; (4) penyusunan desain, programmer bersama-sama peneliti menetapkan rancangan model program berdasar pada informasi data dan konsep yang diperoleh peneliti; (5) penyusunan rancangan, programmer menetapkan dan mulai penyusun rancangan model yang sudah disepakati dengan peneliti; (6) validasi konsep, peneliti melakukan validasi program, apakah sesuai dengan yang dipesan; (7) uji rancangan, dilakukan penilaian kinerja dan kualitas program oleh pengguna (pustakawan) dan ahli pemrograman; (8) maintenance, yaitu upaya menyem-purnakan program terus menerus yang dilakukan oleh programmer; (9) hasil software, program siap diimplemen-tasikan.

Uji coba program dilaksanakan selama 3 (tiga) bulan dengan pertimbangan waktu yang disediakan untuk uji coba telah cukup dikenal oleh pengguna sehingga mereka bisa menilai kualitas program tersebut.

Kriteria yang digunakan dalam form penilaian kinerja software disusun dengan menggunakan indikator-indikator yang diajukan oleh Gilar, meliputi:

(1) Kegunaan, yaitu fasilitas dan laporan yang ada sesuai dengan kebutuhan dan menghasilkan informasi tepat pada waktu (realtime) dan relevan untuk proses pengambilan keputusan.

(2) Ekonomis, yaitu biaya yang dikeluarkan sebanding untuk mengaplikasikan software sesuai dengan hasil yang didapatkan.

(3) Keandalan, yaitu mampu menangani operasi pekerjaan dengan frekuensi besar dan terus-menerus.

(4) Kapasitas, yaitu mampu menyimpan data dengan jumlah besar dengan kemampuan temu kembali yang cepat.

(5) Sederhana, yaitu menu-menu yang disediakan dapat dijalankan dengan mudah dan interaktif dengan pengguna

(6) Fleksibel, yaitu dapat diaplikasikan di beberapa jenis sistem operasi dan institusi serta memiliki potensi untuk dikembangkan lebih lanjut.

Metode yang digunakan dalam pengum-pulan data adalah penyebaran form penilaian. Form disebarkan untuk menggali data kualitas program sistem otomasi presensi pengunjung berbasis ICT 
ini sesudah diterapkan di perpustakaan Undiksha.

Form penilaian yang digunakan untuk menggali data adalah penilaian terhadap kualitas rancangan program sistem presensi pengunjung perpustakaan yang disebarkan kepada seluruh pustakawan di perpustakaan Universitas Pendidikan Ganesha (Ganesha) yang berjumlah 48 orang. Penyebaran form penilaian kepada pustakawan dilakukan setelah rancangan program presensi pengunjung perpustakaan ini diterapkan selama 3 bulan.

Analisis data dilakukan untuk memper-oleh rangkuman data terkait tujuan hasil penelitian, khususnya mengenai kualitas program software yang dinilai oleh pustakawan di lingkungan perpustakaan Undiksha. Hasil penilaian pustakawan merupakan respon pengguna terhadap kualitas rancangan sistem otomasi presensi pengunjung perpustakaan berbasis ICT.

Untuk kriteria penilaian hasil penelitian ditentukan dengan mengkonversikan data angka menjadi kriteria seperti dalam tabel 1 berikut:

Tabel 1. Konversi Data

\begin{tabular}{cc}
\hline Rentang Skor & Kriteria \\
\hline $4,20-5,00$ & Sangat Baik \\
$3,40-4,19$ & Baik \\
$2,60-3,39$ & Cukup \\
$1,80-2,59$ & Kurang \\
$1,00-1,79$ & Sangat Kurang \\
\hline
\end{tabular}

Hasil penelitian dianggap memenuhi target kualitas apabila mendapat nilai ratarata dalam kriteria minimal 'Baik'. Apabila hasil penelitian belum memenuhi target kualitas dimaksud, maka perbaikan program terus dilakukan sampai memperoleh hasil sesuai target kualitas yang telah ditetapkan.

\section{HASIL PENELITIAN}

Pada sistem ini terdapat dua kelompok pengguna program yaitu (1) pengunjung (mahasiswa, dosen, karyawan, serta masyarakat umum) dan (2) pustakawan. Bagi pengunjung penggunaan program ini adalah untuk penggalian data, dimana pengunjung mengakses program sistem ini untuk memasukkan data pribadi mereka yang diperlukan perpustakaan. Data yang dimasukkan berupa Nomor Induk Pegawai (NIP) untuk dosen dan karyawan, Nomor Induk Mahasiswa (NIM) untuk mahasiswa Undiksha, dan kode 000 (angka nol sebanyak 3) untuk masyarakat umum. Sedangkan bagi pustakawan, program ini dapat digunakan untuk melakukan pengolahan data pengunjung perpustakaan menjadi data statistik pengunjung berdasarkan fakultas, program studi, tahun akademik, dan komentarnya terkait penilaian layanan perpustakaan.

Koneksi jaringan data pengunjung atau dalam program dinamakan juga data buku tamu, Sistem jaringan data buku tamu menggunakan sistem jaringan langsung dengan server sehingga data secara otomatis masuk ke database di server perpustakaan. Adapun untuk login program sistem otomasi presensi pengunjung perpustakaan ini digunakan ikon google crome. Login adalah langkah awal masuk ke local host buku tamu.

Cara Menjalankan Program

Langkah memulai menjalankan program ini adalah sebagai berikut:

- Nyalakan komputer dengan menekan tombol Power pada CPU

- Tunggu hingga dilayar muncul Desktop Windows

- Klik ikon Mozilla Firefox pada layar bawah atau bisa juga di layar desktop (customize taskbar).

- Tunggu sampai di layar monitor tampil lembar aplikasi program presensi pengunjung perpustakaan seperti gambar berikut:

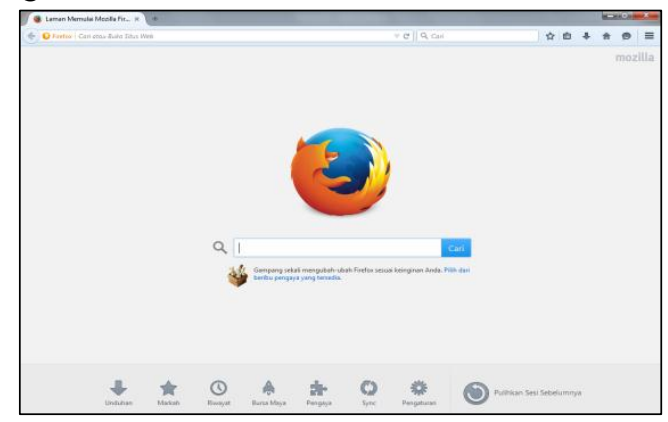

Gambar 2. Tampilan Awal 


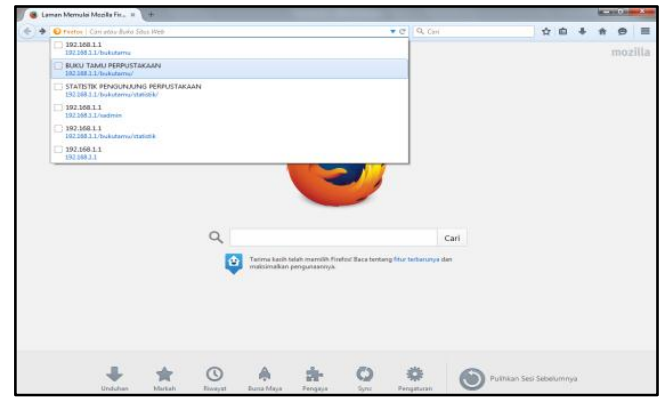

Gambar 3. Tampilan Awal

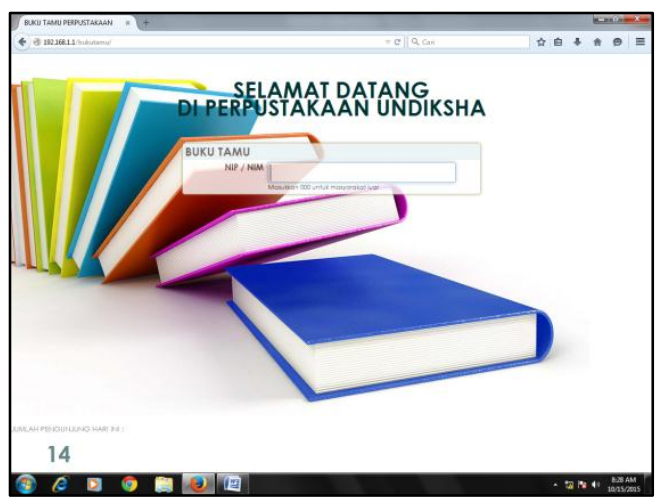

Gambar 4. Tampilan Presensi Pengunjung

Pada layar "Selamat Datang di Perpustakaan Undiksha" menyediakan kotak isian buku tamu untuk pengunjung perpustakaan Undiksha.

\section{Menjalankan Presensi Pengunjung}

- Mengisi identitas diri di kotak NIP/NIM pada layar "Buku Tamu". Pengisian data ini wajib dilakukan pengunjung dengan ketentuan berikut:

- Mahasiswa memasukkan data NIM

- Karyawan/dosen Undiksha memasukkan data NIP

- Masyarakat umum memasukkan angka 000.

- Klik enter untuk menyetujui isi data sekaligus mengakhiri pengisian data.

Sebagai contoh dimasukkan data NIM atas nama "Ni Nyoman Ayu Juita Ersani" dengan NIM 131201033.

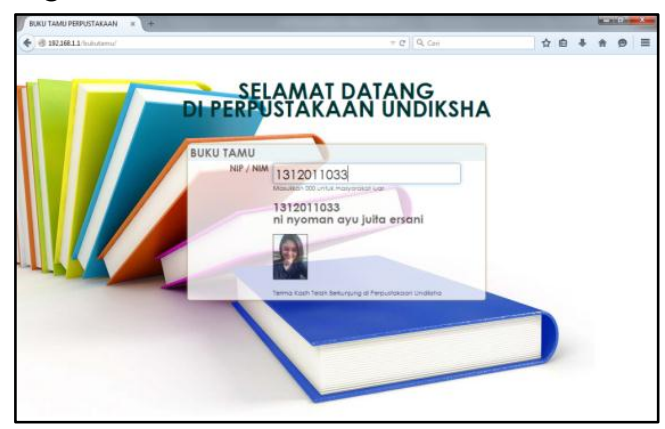

Dengan mengetik NIM, data nama dan foto mahasiswa tersebut akan tampil di layar.

Menjalankan Program Statistik

- Klik mesin telusur jaringan (browser).

- Selanjutnya pilih dan klik "statistik pengunjung perpustakaan".

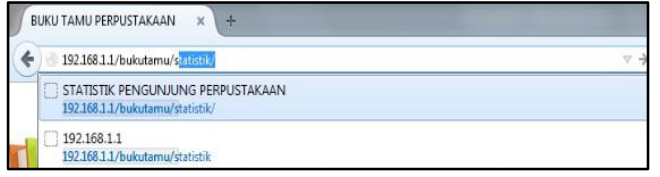

Gambar 5: Pilihan di Browser

- Tunggu sampai muncul tampilan berikut:

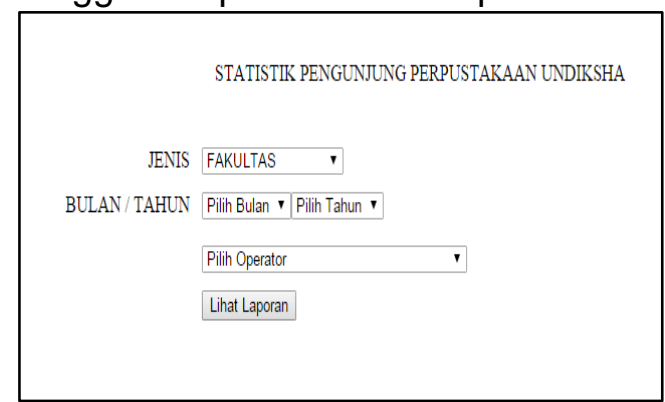

Gambar 6. Pilihan Data

Untuk membuka dan mencetak data statistik berdasarkan jenis pilihan fakultas dilakukan langkah-langkah berikut:

- Klik tanda panah (dropdown) pada kotak "Jenis".

- Pilih "Fakultas" untuk melihat/membuat statistik data pengunjung perpustakaan berdasarkan fakultas.

- Pilih "Tahun" dan tentukan tahun 2015.

- Selanjutnya klik kotak "Lihat Laporan".

- Berikut akan tampil data "Statistik Pengunjung Perpustakaan Berdasar Asal Tahun 2015" seperti gambar di bawah ini.

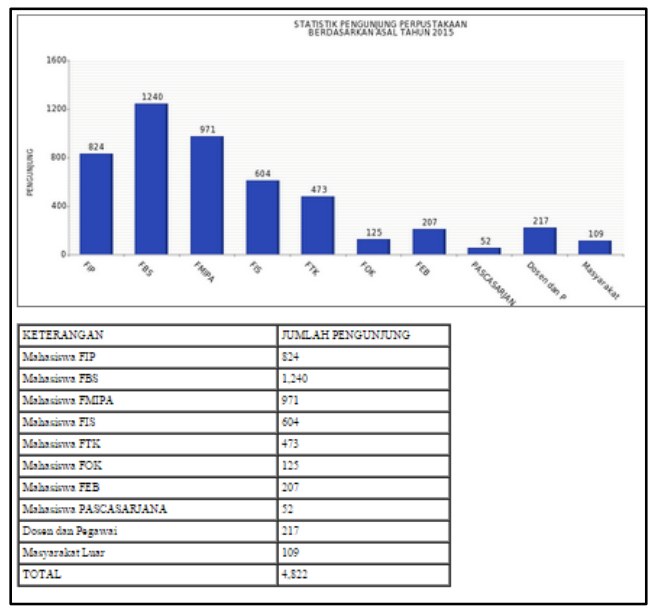

Gambar 7. Statistik Asal Pengunjung

Jurnal Sains dan Teknologi | 800 
Lakukan langkah-langkah berikut ini untuk mencetak hasil pengolahan statistik data pengunjung perpustakaan berdasarkan fakultas untuk tahun 2015.

- Klik ikon menu yang ada di pojok kanan atas.

- Klik Print untuk mencetak.

Berikut muncul kotak dialog print seperti tampilan di bawah ini.

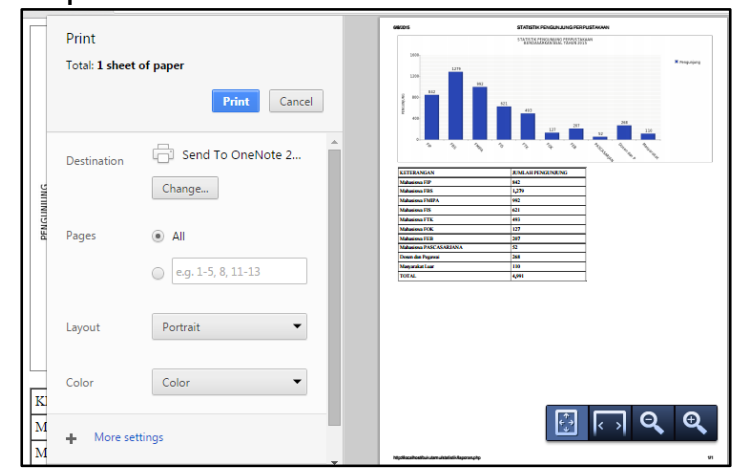

Gambar 8. Kotak Dialog Print

Langkah langkah untuk membuka/ melihat data statistik jenis pilihan "program studi" relatif sama dengan langkah-langkah pada jenis pilihan "fakultas". Berikut ini langkahlangkah yang harus dilakukan:

- Klik tanda panah pada kotak "Jenis", lanjut klik "Program Studi".

- Pilih "Tahun" dan tentukan tahun 2015

- Klik "Lihat Laporan".

- Selanjutnya akan tampil data "Statistik Pengunjung Perpustakaan berdasar Program Studi".

Langkah untuk melakukan pencetakan sama dengan langkah-langkah yang telah dijelaskan pada pencetakan data statistik pengunjung berdasarkan jenis pilihan fakultas di depan.

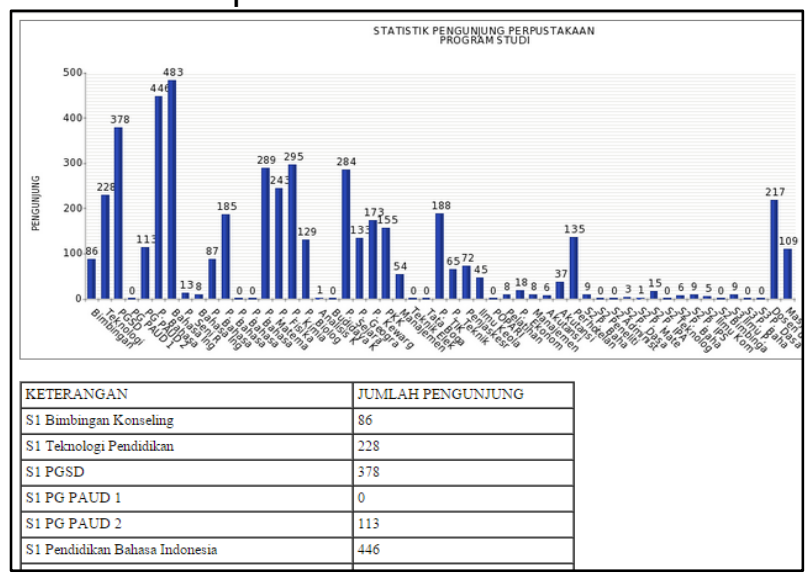

Gambar 9. Statistik Program Studi
Untuk membuka dan mencetak pilihan lainnya secara umum tidak berbeda dengan penjelasan membuka statistik berdasarkan program studi di atas.

\section{Kinerja Program Presensi}

Data penilaian terkait kualitas program software diperoleh dari penyebaran angket terhadap 28 pengguna atau pustakawan sebagai penilai. Selanjutnya penilai memberikan tanggapan positif terhadap kualitas program. Penilaian disimbolkan dalam bentuk angka. Pilihan tertinggi adalah angka 5 yang menyatakan bahwa penilai memberikan tanggapan positif antara $90 \%$ sampai dengan $100 \%$, pilihan terendah adalah angka 1 yang menyatakan penilai memberikan tanggapan positif antara $0 \%$ sampai dengan $54 \%$. Skor ratarata pilihan penilai selanjutnya dikonversi menjadi 5 (lima) kriteria yaitu: (1) Sangat Baik; (2) Baik; (3) Cukup; (4) Kurang; dan (5) Sangat Kurang. Hasil penelitian dianggap berhasil atau memenuhi kriteria keberhasilan apabila mendapat rata-rata skor dalam kategori 'Baik' atau 'Sangat Baik' pada masing-masing indikator yang dinilai. Apabila hasil penelitian belum memenuhi kriteria keberhasilan dimaksud, maka perbaikan program terus dilakukan sampai memper-oleh hasil sesuai kriteria keberhasilan yang telah ditetapkan.

Terdapat 3 (tiga) indikator kriteria yang dinilai terkait kualitas program, yaitu (1) kegunaan, (2) keandalan, dan (3) sederhana. Dalam penyusunan instrumen penilaian, masing-masing indikator diwakili oleh 3 pertanyaan sehingga jumlah seluruhnya sebanyak 9 pertanyaan. Dari penyebaran angket terhadap 28 pengguna diperoleh data hasil penilaian pengguna yang disampaikan dalam bentuk tabel 2 
Tabel 2. Data hasil penyebaran angket

\begin{tabular}{|c|c|c|c|c|c|c|c|c|}
\hline \multirow[t]{2}{*}{$\sqrt{ }$} & \multicolumn{5}{|c|}{$\begin{array}{l}\text { Skor dan jumlah } \\
\text { pemilih }\end{array}$} & \multirow{2}{*}{$\begin{array}{l}\Sigma \\
\text { sk } \\
\text { or }\end{array}$} & \multirow{2}{*}{$\begin{array}{l}\text { Rerat } \\
\text { a skor }\end{array}$} & \multirow[t]{2}{*}{ Kriteria } \\
\hline & 5 & 4 & 3 & 2 & 1 & & & \\
\hline \multicolumn{6}{|c|}{$\begin{array}{l}\text { Kriteria 1: Kegunaan } \\
\text { Program }\end{array}$} & & & \\
\hline & \begin{tabular}{l|}
1 \\
7
\end{tabular} & $\begin{array}{l}1 \\
0\end{array}$ & 1 & 0 & 0 & $\begin{array}{c}12 \\
8\end{array}$ & 4,57 & SB \\
\hline & $\begin{array}{l}2 \\
0\end{array}$ & 4 & 4 & 0 & 0 & $\begin{array}{c}12 \\
8\end{array}$ & 4,57 & SB \\
\hline & $\begin{array}{l}1 \\
6\end{array}$ & $\begin{array}{l}1 \\
1\end{array}$ & 1 & 0 & 0 & $\begin{array}{c}12 \\
7\end{array}$ & 4,54 & SB \\
\hline \multirow{2}{*}{\multicolumn{6}{|c|}{$\begin{array}{l}\text { Rata-rata Kriteria } 1 \\
\text { Kriteria 2: Keandalan } \\
\text { Program }\end{array}$}} & & 4,56 & $S B$ \\
\hline & & & & & & & & \\
\hline & $\begin{array}{l}1 \\
6 \\
\end{array}$ & $\begin{array}{l}1 \\
0 \\
\end{array}$ & 2 & 0 & 0 & $\begin{array}{c}12 \\
6 \\
\end{array}$ & 4,50 & SB \\
\hline & $\begin{array}{l}1 \\
0\end{array}$ & $\begin{array}{l}1 \\
6\end{array}$ & 2 & 0 & 0 & $\begin{array}{c}12 \\
0\end{array}$ & 4,29 & SB \\
\hline & $\begin{array}{l}2 \\
0 \\
\end{array}$ & 8 & 0 & 0 & 0 & $\begin{array}{c}13 \\
2\end{array}$ & 4,71 & SB \\
\hline \multicolumn{7}{|c|}{ Rata-rata Kriteria 2} & 50 & $\overline{S B}$ \\
\hline \multicolumn{6}{|c|}{$\begin{array}{l}\text { Kriteria 3: } \\
\text { Kesederhanaan } \\
\text { Program }\end{array}$} & & & \\
\hline & $\begin{array}{l}1 \\
9\end{array}$ & 9 & 0 & 0 & 0 & $\begin{array}{c}13 \\
1\end{array}$ & 4,68 & SB \\
\hline & $\begin{array}{l}1 \\
8\end{array}$ & $\begin{array}{l}1 \\
0\end{array}$ & 0 & 0 & 0 & $\begin{array}{c}13 \\
0\end{array}$ & 4,64 & SB \\
\hline & \begin{tabular}{|l|}
2 \\
2 \\
\end{tabular} & 6 & 0 & 0 & 0 & $\begin{array}{c}13 \\
4 \\
\end{array}$ & 79 & SB \\
\hline & & & & & & & 4,70 & $S$ \\
\hline
\end{tabular}

Berikut ini disampaikan hasil analisis data sebagai berikut.

\section{Penilaian terhadap Kegunaan Program}

Data mengenai penilaian terhadap kegunaan program sistem otomasi presensi pengunjung berbasis ICT di Perpustakaan Undiksha (kriteria 1), terbagi dalam 3 (tiga) subbagian yang masing-masing diwakili oleh satu pertanyaan, yaitu pertanyaan (1) mengenai efisiensi program dalam pengolahan data statistik, pertanyaan (2) mengenai relevansi hasil program dengan kebutuhan pembuatan statistik perpustakaan, dan pertanyaan (3) mengenai relevansi hasil program dengan kebutuhan layanan informasi perpustakaan.

Dari tabel 02 di atas terlihat bahwa dari 28 responden, untuk pertanyaan nomor 1 , sebanyak 17 responden memberi skor 5 dan 10 responden memberi skor 4 , serta hanya 1 responden memberi skor 3 . Sesudah dirata-rata diperoleh skor sebesar 4,57. Apabila ditarik dalam tabel konversi termasuk dalam kategori 'Sangat Baik'. Penilaian dengan hasil sama terdapat pada pertanyaan nomor 2 yaitu 20 responden memberi skor 5 dan 4 responden memberi skor 4 , serta 4 lainnya memberi skor 3 , sehingga diperoleh rata-rata skor sebesar 4,57 atau dalam kategori 'Sangat Baik'. Untuk pertanyaan nomor 3 sebanyak 16 responden memberi skor 5 dan 11 responden memberi skor 4 serta 1 lainnya memberi skor 3 , sehingga diperoleh ratarata skor sebesar 4,54 atau dalam kategori 'Sangat Baik'. Hasil dari ketiga pertanyaan tersebut apabila di rata-rata diperoleh skor sebesar 4,56 atau masuk dalam kategori 'Sangat Baik'.

Hasil penilaian ini memberikan gambaran bahwa kiperja program software sistem otomasi presensi pengunjung berbasis ICT untuk Perpustakaan Undiksha yang disusun dalam penelitian ini telah menunjukkan kualitas yang 'Sangat Baik' untuk kinerjanya di bidang kegunaan program.

Penilaian terhadap Keandalan Program

Data mengenai penilaian terhadap keandalan program sistem otomasi presensi pengunjung berbasis ICT di Perpustakaan Undiksha (kriteria 2), juga terbagi dalam 3 (tiga) subbagian yang masing-masing diwakili oleh satu pertanyaan, yaitu pertanyaan pertama (nomor urut 4) mengenai kemampuan program dalam menangani pengolahan data skala besar/banyak, pertanyaan kedua (nomor urut 5) mengenai keandalan program dalam mengolah data terusmenerus, dan pertanyaan ketiga (nomor urut 6) mengenai kemampuan atau keandalan program secara keseluruhan.

Hasil penilaian menyatakan, untuk pertanyaan pertama sebanyak 16 responden memberi skor 5 dan 10 responden memberi skor 4 serta 2 responden memberi skor 3 . Sesudah diratarata diperoleh skor sebesar 4,50 dan bila ditarik dalam tabel konversi termasuk dalam kategori 'Sangat Baik'. Untuk pertanyaan kedua sebanyak 10 responden memberi 
skor 5 dan 16 responden memberi skor 4 , serta 2 lainnya memberi skor 3, sehingga diperoleh rata-rata skor sebesar 4,29 atau dalam kategori 'Sangat Baik'. Sedangkan pertanyaan nomor 3 sebanyak 20 responden memberi skor 5 dan 8 responden memberi skor 4, sehingga diperoleh rata-rata skor sebesar 4,71 atau dalam kategori 'Sangat Baik'. Hasil dari ketiga pertanyaan tersebut apabila di ratarata diperoleh skor sebesar 4,50 atau masuk dalam kategori 'Sangat Baik'.

Hasil penilaian ini memberikan gambaran bahwa kinerja program software sistem otomasi presensi pengunjung berbasis ICT untuk Perpustakaan Undiksha yang disusun dalam penelitian ini telah menunjukkan kualitas yang 'Sangat Baik' untuk kinerjanya di bidang keandalan program.

\section{Penilaian Kesederhanaan Program}

Sebagaimana penilaian lainnya, data penilaian terhadap kesederhanaan program sistem otomasi presensi pengunjung berbasis ICT di Perpustakaan Undiksha (kriteria 3), juga terbagi dalam 3 (tiga) subbagian yang masing-masing diwakili oleh satu pertanyaan, yaitu pertanyaan pertama (nomor urut 7) mengenai efektivitas penggunaan program secara keseluruhan, pertanyaan kedua (nomor urut 8) mengenai efektivitas penggunaan menumenu program, dan pertanyaan ketiga (nomor urut 9) adalah efektivitas penggunaan petunjuk-petunjuk program untuk kemudahan kerja.

Hasil penilaian adalah untuk pertanyaan pertama terdapat 19 responden memberi skor 5 dan 9 responden memberi skor 4, sehingga rata-rata diperoleh skor sebesar 4,68 atau dalam kategori 'Sangat Baik'. Untuk pertanyaan kedua sebanyak 18 responden memberi skor 5 dan 10 responden memberi skor 4 , sehingga bila di rata-rata diperoleh skor sebesar 4,64 atau termasuk dalam kategori 'Sangat Baik'. Untuk pertanyaan ketiga sebanyak 22 responden memberi skor 5 dan 6 responden memberi skor 4 , sehingga ratarata diperoleh skor sebesar 4,79 atau termasuk dalam kategori 'Sangat Baik'. Hasil dari ketiga pertanyaan tersebut sesudah dirata-rata diperoleh skor sebesar
4,70 atau masuk dalam kategori 'Sangat Baik'.

Hasil penilaian ini memberikan gambaran bahwa kinerja program software sistem otomasi presensi pengunjung berbasis ICT untuk Perpustakaan Undiksha yang disusun dalam penelitian ini telah menunjukkan kualitas yang 'Sangat Baik' untuk kinerjanya di bidang kesederhanaan program.

Secara keseluruhan penilaian terkait kualitas software program sistem otomasi presensi pengunjung berbasis ICT ini sudah menunjukkan kinerja yang baik. Hal ini dibuktikan dari hasil penilaian para pustakawan secara keseluruhan sudah termasuk dalam kategori 'Sangat Baik', sehingga dapat ditarik kesimpulan bahwa kriteria keberhasilan yang telah ditetapkan dalam penelitian ini sudah tercapai.

\section{Kualitas Program Presensi}

Dalam kegiatan penilaian kualitas program software ini peneliti melibatkan Bapak Ida Komang Widhiarjaya, ST. sebagai penilaian ahli. Form penilaian terdiri dari 6 (enam) komponen penilaian sebagaimana form yang telah disampaikan pada bab iii di depan. Sebagaimana penilaian kinerja, pada penilaian kualitas program ini juga menggunakan 5 (lima) kriteria yaitu: (1) Sangat Baik; (2) Baik; (3) Cukup; (4) Kurang; dan (5) Sangat Kurang.

Data hasil penilaian oleh pakar atau ahli pemrograman dapat disampaikan dalam tabel 3 berikut.

Tabel 3. Data hasil penilaian Pakar

\begin{tabular}{lcc}
\hline \multicolumn{1}{c}{ Indikator } & Skor & $\begin{array}{c}\text { Rerata } \\
\text { Skor }\end{array}$ \\
\hline Pewarnaan & 4 & $4(\mathrm{~B})$ \\
Interaktif menu dan ikon & 3 & $4(\mathrm{~B})$ \\
& 5 & \\
Desain Interface & 4 & $4(\mathrm{~B})$ \\
Pengoperasian program & 4 & \\
Keamanan program & 5 & $5(\mathrm{SB})$ \\
Penanganan kesalahan & 5 & $5(\mathrm{SB})$ \\
Responsif & 5 & $5(\mathrm{SB})$ \\
Ketepatan input \& output & 5 & $5(\mathrm{SB})$ \\
\multicolumn{4}{c}{ Rata-rata } & $4(\mathrm{~B})$ \\
& & $(\mathrm{SB})$ \\
\hline
\end{tabular}


Di bawah ini disampaikan berturutturut uraian hasil analisis data hasil penilaian pakar atau ahli yang terdiri dari 8 (delapan) indikator.

\section{Pewarnaan Program}

Pewarnaan program adalah kondisi tampilan yang muncul apabila program dijalankan. Indikator ini akan semakin baik penilaiannya apabila penggunaan warna tidak mengacaukan tampilan secara menyeluruh. Hasil penilaian untuk pewarnaan memperoleh skor 4 dan bila ditarik dalam tabel konversi termasuk dalam kriteria 'Baik'. Kriteria ini memberikan gambaran bahwa aspek pewarnaan tampilan program sudah sesuai harapan yaitu program ini telah memiliki tampilan program yang layak digunakan secara menyeluruh sehingga menarik bagi pengguna.

\section{Interaktif Menu dan Ikon}

Interaktif menu dan ikon adalah tersedianya berbagai pilihan menu dan ikon serta terdapatnya tombol menu dan ikon yang tepat untuk mengarahkan pengguna dalam mengoperasikan program. Penilaian interaktif menu dan ikon ini terbagi dalam 2 (dua) penilaian yaitu (1) nilai pilihan menu dan ikon, dan (2) nilai tombol ikon dan menu. Kedua nilai ini masing-masing mendapat rata-rata skor $=4$. Bila ditarik dalam tabel konversi termasuk dalam kriteria 'Baik'. Kriteria ini memberikan gambaran bahwa untuk aspek interaktif menu dan ikon sudah layak digunakan dalam program.

\section{Desain Interface}

Desain interface merupakan rancangan yang digunakan untuk menghubungkan antar tampilan dengan tujuan memudahkan pengguna dalam melakukan proses pencarian data. Dari dua penilaian mengenai rancangan desain interface yang diajukan memperoleh skor rata-rata $=4$ atau dalam kriteria 'Baik'. Hal ini mengindikasikan bahwa rancangan desain interface dalam program ini sudah sesuai harapan yaitu dapat meningkatkan kualitas layanan sehingga layak digunakan dalam program.

\section{Pengoperasian Program}

Pengoperasian program merupakan suatu rancangan yang disusun guna memper-mudah

pengguna/pemakai sehingga dapat dijalankan program dengan baik. Dari 2 aspek penilaian diperoleh skor maksimal dengan rata-rata $=5$. Bila dikonversikan berada pada kriteria 'Sangat Baik'. Hasil penilaian ini mengindikasikan bahwa aspek pengoperasian program telah berfungsi sempurna sehingga mempermudah peng-guna dalam mengoperasikan program serta dapat dijalankan dengan sangat baik dalam kondisi normal.

\section{Keamanan Program}

Keamanan program merupakan rancangan yang paling penting untuk diperhatikan oleh programmer. Apabila programmer tidak mampu mengamankan program yang disusun, maka pengguna yang tidak bertanggung jawab akan dapat mengubah/ merusak program atau mudah diserang oleh hacker sehingga fungsi program akan kacau atau bahkan dapat disalahgunakan. Oleh karena itu keamanan program mendapat prioritas utama dalam penyusunan program ini dengan tujuan menutup kemungkinan adanya kesalahan atau peluang perusak program (hacker) mengacaukannya. Penilaian terkait keamanan progam ini memperoleh skor maksimal (rata-rata $=5$ ) atau termasuk dalam kriteria 'Sangat Baik'. Ini berarti bahwa aspek keamanan program sudah sesuai harapan yaitu dapat menghilangkan peluang hacker untuk bermain atau mengubah/merusak program.

\section{Penanganan Kesalahan}

Penanganan kesalahan adalah penilaian terhadap kerja program. Program yang baik adalah program yang bebas dari kesalahan yang mengakibatkan berhentinya program saat dioperasikan atau menghasilkan output yang tidak valid. Penilaian dari aspek ini memperoleh skor = 5 atau termasuk dalam kategori 'Sangat Baik'. Hasil nilai ini sudah sesuai harapan yaitu aspek penanganan kesalahan dalam program ini sudah berfungsi dengan baik atau memiliki tingkat kesalahan yang sangat rendah sehingga sudah layak untuk digunakan.

Responsif

Responsif adalah penilaian terhadap berjalan/tidaknya program di semua sistem 
operasinya. Program yang baik adalah program yang bisa dijalankan semua sistem operasi tanpa ada kendala operasinya (seperti hang, kesalahan sistem dan lainnya) yang dapat mengacaukan atau menghambat operasional program. Penilaian dari aspek responsif ini juga memperoleh skor $=5$ atau termasuk dalam kategori 'Sangat Baik'. Hasil nilai ini sudah sesuai harapan yaitu responsif program sudah berfungsi dengan baik atau memiliki tingkat kesalahan yang sangat rendah sehingga sudah layak untuk digunakan.

\section{Ketepatan Input dan Output}

Ketepatan input dan output adalah penilaian terhadap tampilan hasil kerja (kinerja) program. Program yang baik adalah program yang dapat menampilkan hasil sesuai dengan input yang dimasukkan. Penilaian dari aspek ini memperoleh skor 4 atau termasuk dalam kategori 'Baik'. Hasil nilai ini sudah sesuai harapan yaitu ketepatan input dan output program memiliki kualitas baik atau memiliki tingkat kesalahan yang sangat rendah sehingga sudah layak untuk digunakan.

Secara keseluruhan penilaian terkait bidang kualitas software program sistem otomasi presensi data berbasis ICT ini juga sudah menunjukkan kinerja yang tinggi. Hasil penilaian pakar komputer mendapat skor rata-rata sebesar 4,50 sehingga termasuk dalam kategori 'Sangat Baik'.

\section{PEMBAHASAN}

Sistem penyusunan statistik data di perpustakaan Universitas Pendidikan Ganesha yang dilakukan selama ini bersifat manual. Selain tidak efisien sistem ini uga rawan adanya kesalahan. Hal ini sangat mungkin terjadi mengingat besaran data koleksi buku yang relatif tinggi dan kompleksnya data yang diolah untuk laporan. Penyusunan laporan dengan jalan pintas (tidak melalui prosedur) yaitu dengan menggunakan copy paste dari data report tahun sebelumnya dan memodifikasi dengan perkiraan perkembangan dan keperluan sudah sering dilakukan untuk memenuhi permintaan/kebutuhan laporan. Tentu saja laporan ini tidak menggambarkan kondisi data sebenarnya (data tidak valid) dan data yang tidak valid merupakan data yang menyesatkan. Apabila data tersebut digunakan sebagai bahan dasar penyusunan suatu program, maka sangat riskan terjadinya kelemahan dari rancangan program yang disusun tersebut dan muaranya adalah kurang optimalnya hasil dari implementasi program.

Kegiatan penelitian ini penting dilakukan guna menjembatani permasalahan tersebut. Inti dari kegiatan penelitian ini adalah upaya meningkatkan kualitas laporan statistik data pengunjung perpustakaan dengan menge-depankan prinsip efektif, efisien, valid, dan sahih. Hasil penelitian yang berupa program software ini selanjutnya diujicoba kelayakan-nya oleh pustakawan sebagai pengguna untuk pembuktian sebagaimana yang telah ditetapkan dalam tujuan penelitian ini.

Dari hasil penelitian ini diperoleh 3 (tiga) temuan penting yaitu: (1) proses kerja program sistem otomasi statistik dalam mengolah data presensi pengunjung berupa report tabel dan grafik yang dijabarkan dalam bentuk tampilan, menu, dan ikon sehingga memudahkan pengguna dalam mengoperasionalkan program software ini; (2) kinerja program sistem otomasi presensi data pengunjung perpustakaan yang mendapat penilaian dan tanggapan positif dari pustakawan sebagai pengguna program. Secara umum pustakawan menilai kinerja program ini dalam kategori 'Sangat Baik". Ini bisa diartikan bahwa dari sisi aplikatif software program sistem otomasi presensi data pengunjung perpustakaan ini sudah layak untuk digunakan sebagaimana fungsinya; (3) kualitas program sistem otomasi statistik data pengunjung perpustakaan yang mendapat penilaian dan tanggapan positif dari pustakawan sebagai pengguna program. Secara umum penilaian pustakawan sebagai pengguna program software ini menyatakan kualitas program ini dalam kategori 'Sangat Baik". Ini bisa diartikan bahwa dari sisi aplikatif software program sistem otomasi statistik data pengunjung per-pustakaan dalam bentuk report tabel dan grafik ini sudah layak untuk digunakan sebagaimana fungsinya. 
Temuan-temuan dari hasil penelitian ini sesuai dengan fungsi dari pemanfaatan teknologi informasi pada perpustakaan khususnya untuk mendukung keperluan layanan perpustakaan. Dari 6 (enam) manfaat komputer di perpustakaan (Depdiknas, 2004:20), minimal 2 (dua) manfaat dapat dibuktikan kebenarannya yaitu efisiensi waktu dan kebutuhan akan kecepatan layanan. Sedangkan dari segi manfaat sosial, dari 7 kategori yang disampaikan Santika dalam buku Pengantar Teknologi Informasi (2004:101102), minimal 3 (tiga) kategori sesuai hasil penelitian ini yaitu manfaat Acceptancy, Accessibility \&Duplicatability/Distributability.

Dari sisi manfaat, program software ini juga mempermudah pustakawan dalam mengelola data dan menyusun berbagai laporan statistik terkait data perpustakaan secara efektif dan efisien serta dapat dipertanggungjawabkan validitas datanya. Dengan diterapkannya program software ini maka permintaan akan laporan statistik data pengunjung perpustakaan yang bersifat mendadak, bisa terlayani dan dapat dipertanggung-jawabkan kebenarannya.

Mencermati temuan ini, maka diharapkan hasil penelitian ini dapat diimplikasikan di dalam program kerja perpustakaan ke depan, sebagai salah satu poin penting dalam pengambilan keputusan arah kebijakan perpustakaan di Universitas Pendidikan Ganesha, mengingat pentingnya peran dan mendesaknya keperluan program software terkait laporan statistik data perpustakaan. Hasil temuan ini apabila diimplementasikan pada perpustakaan lain juga diyakini mampu meningkatkan kualitas layanan laporan perpustakaan, khususnya layanan laporan statistik data perpustakaan.

\section{SIMPULAN}

Sesudah rancangan program sistem otomasi presensi pengunjung perpustakaan berbasis ICT ini disusun dan diterapkan di perpustakaan Universitas Pendidikan Ganesha diperoleh simpulan bahwa, (1) deskripsi implementasi program relatif praktis, dimana program terbagi dalam 3 (tiga) jenis pilihan yaitu: (a) jenis data, dan (b) tahun data. Tampilan program sangat sederhana dan mudah dipahami karena berupa menu dan ikon, sehingga pengguna tidak perlu mengetik. Untuk menu pilihan disediakan menu dropbox sehingga pengguna hanya meng-klik menu atau ikon; (2) Dari segi kinerja program, penyusunan software program sistem otomasi statistik data presensi pengunjung perpustakaan ini dinilai "Sangat Baik" sehingga program ini sudah layak diterapkan. (3) Dari segi kualitas program, penyusunan software program sistem otomasi statistik data presensi pengunjung perpustakaan dalam bentuk report tabel dan grafik ini dinilai "sangat baik" sehingga program ini sudah layak diterapkan.

Dari hasil penelitian ini diajukan saran/ rekomendasi untuk meningkatkan layanan perpustakaan, khususnya layanan penyusunan laporan statistik data pengunjung perpustakaan. Saran meliputi: (1) program sistem otomasi statistik data pengunjung perpustakaan dalam bentuk report tabel dan grafik ini hendaknya diberlakukan di perpustakaan Undiksha; (2) mengingat perkembangan Information Communication Technologies (ICT) yang cepat dan keterbatasan sumber daya manusia (SDM) di perpustakaan Universitas Pendidikan Ganesha, maka perlu diadakan spesialisasi penguasaan ICT pada masingmasing pustakawan. Spesialisasi penguasaan ICT juga sangat berguna dalam mempercepat pemahaman dan penguasaan materi. Misalnya dalam melaksanakan tugas ada pustakawan yang spesialisasinya input data, pustakawan yang spesialisasinya di bidang pemrograman, spesialisasi operator, dan lainnya. Kebijakan melakukan rotasi tugas per tahun yang selama ini dijalankan di perpustakaan Undiksha hendaknya ditinjau kembali efektivitas dan efisiensinya; (3) mengingat pentingnya peran komputer dalam kegiatan entry data, maka perlu diadakan pengadaan komputer yang spesifikasinya memadai, demikian juga jumlah komputer harus mencukupi keperluan. 


\section{DAFTAR PUSTAKA}

Budi Sutejo Dharma Oetomo, 2002.

Perencanaan dan Pembangunan

Sistem Informasi. Yogyakarta: Andi

Offset.

Depdiknas, 2004. Pemanfaatan Teknologi Informasi pada Perpus-takaan. Jakarta.

Gatot Subroto, 2010. Otomasi Perpustakaan.

http://libraryconer.org/2010/10/12/ otomasi perpustakaan/diakses tanggal 04 Pebruari 2012.

Santika, 2004. Pengantar Teknologi Informasi.

http://librarycorner.org/2007/

02/28/diunduh tanggal 11 Agustus 2012. 